\section{Tuition Fee Reform in Germany}

\section{Barbara M. KeHM}

Barbara M. Kehm is professor and director at the International Centre for Higher Education Research, University of Kassel. Address: Moenchebergstr. 17, D-34109 Kassel, Germany. E-mail: kehm@hochschulforschung.uni-kassel.de.

The introduction of tuition fees has brought about a longterm debate in Germany. While the majority of political actors and institutional decision makers wanted tuition fees in the higher education sector, the various stakeholder groups failed to agree on who should gain access to the extra revenue and thus blocked the policy decision. The responsible state government ministries wanted to save money by reducing the budget allocations to higher education institutions based on the income provided by tuition fees. The rectors and presidents rejected this idea and voted against tuition fees as long as state governments did not offer guarantees that institutions could invest this extra income, in particular for the improvement of teaching quality. Politically, the Social Democrats opposed and the Christian Democrats favored the introduction of tuition fees.

Gradually, tuition fees have been introduced on the margins of the German higher education system. First, tuition fees were charged for continuing academic education and lifelonglearning provisions. Then the German states started to demand tuition fees from students who were enrolled more than four semesters beyond the standard period. The administrative fees for student reenrollments each semester increased as well.

The last amendment to the German Higher Education Framework Law under the Social Democratic coalition government in 2002 included an explicit prohibition of tuition fees for undergraduate programs. Six of the German states-all of them governed by the Christian Democrats or a conservative coalition-brought action to the Constitutional Court, calling the federal government's prohibition of fees an unconstitutional interference into the budgetary autonomy of the states with regard to higher education.

In January 2005 the Constitutional Court ruled in favor of the German states-declaring the prohibition of tuition fees under the Higher Education Framework Law to be unconstitutional and allowing the states to levy tuition fees. The controversial debate intensified. The court's decision seemed not only to be the beginning of the end of any higher education framework law guaranteeing a certain amount of systemic uniformity but also evidence of a change from the idea of education as a public good to the idea of education as a private good.

\section{The Present Reform}

Soon after the decision, the first German states announced their intent to introduce tuition fees. The general idea was to ask for 500 euros per semester in all subjects. Most of the states kept their previous regulations regarding administration fees for reenrollment and tuition fees for long-term students and continuing academic education provisions. In addition, the majority of states are about to introduce fees for undergraduate and graduate education. But there are considerable policy differences among the $\mathrm{i} 6$ German states.

All the eastern German states as well as Berlin, regardless which political party is in power, are currently not planning to introduce tuition fees. They hope to have a competitive advantage and thus be able attract those German students into their higher education institutions who want to avoid paying tuition fees. In addition, Rhineland-Palatinate is also not planning to introduce tuition fees. The remaining nine German states plan

\section{Gradually, tuition fees have been introduced on} the margins of the German higher education system.

to introduce tuition fees of about 500 euros per semester starting in the 2006/07 winter semester or in the 2007 summer semester. However, the conditions and tuition-related regulations differ in some states. For example, Bremen will only require tuition fees from students living outside the city state. Hesse would like to introduce tuition fees but will first need to amend the state constitution, which now prohibits such fees. Bavaria will charge different tuition fees at a university and at a university of applied sciences (Fachhochschule). In North Rhine-Westphalia, the government allows higher education institutions to decide the level of fees, ranging from $o$ and 500 euros. Furthermore, some differences exist in procedures involving international students, regulations for receiving and repaying loans, or conditions to become exempted from paying fees.

\section{Consequences and Concerns of Access}

Almost all German states (except Hamburg) are planning to introduce tuition fees by $2006 / 07$ or 2007 . While the actual consequences can only be examined in the future, there are a number of concerns and anticipated consequences. In particular, it is said that the willingness of young people coming from low-income families to engage in higher education may result in some negative impacts. In terms of access, the situation is going to become even more complex. Three aspects are worth mentioning here: (a) student mobility within Germany; (b) recognition of certificates and achievements earned in another German state; and (c) the selection of students by higher education institutions.

It is expected that the anticipated differentiation of fees will 
hinder student mobility within Germany-depending on the state, the higher education institution, and possibly the subject. However, eastern German states following a tuition-free policy will profit from some student migration from states that will demand tuition fees.

The establishment of an elite sector within the German higher education system on the basis of the "initiative for excellence" as well as other complications may lead to a further differentiation of institutions and tuition fees, as well as reducing intra-German mobility. It is expected that universities succeeding in the initiative will eventually ask for considerably higher fees than other universities.

Universities counting themselves as part of the elite group will restrict access and heighten selectivity. Other institutions will follow this approach, because they fear being left with students rejected as unqualified by the elite universities. The principles of free access and students choosing their higher education institutions will be reversed.

This is a slightly revised version of an article originally published (in English and French) in IAU Horizons 2, May 2006. The author thanks the Association of International Universities for the permission to publish this revised version.

\section{Presidential Politics and Higher Education Reforms in Mexico}

\section{Alma Maldonado-Maldonado}

Alma Maldonado-Maldonado is assistant professor at the Center for the Study of Higher Education, University of Arizona. Address: 327-B Education, Tucson, Arizona, 85721, USA. E-mail: maldona2@arizona .email.edu.

$\mathrm{T}$ he Vicente Fox administration is coming to an end. In 2000 , Fox was the first president elected from a political party other than PRI (the Institutional Revolutionary Party), which ruled Mexico for more than 75 years. When PAN (the National Action Party) won the last elections many expectations were created about Fox's presidency, given the victory of a different political party.

Discussing Fox's legacy in higher education seems pertinent at this moment. Mexican presidential elections took place on July 2 nd, and the conservative candidate was declared the victor in a disputed decision. This article discusses the extent to which a political transition influences higher education reform in a Latin American country. This analysis seems necessary due to the various political changes that have occurred on the continent recently. There is no intention, however, to simplify the complex task of reforming higher education institutions.

\section{Main In ITIATIVES IN the Fox Administration}

The four principal higher education initiatives emphasized during the six years of Fox's government include: the Integral Program for Institutional Strengthening (PIFI—all acronyms in this article are based on the Spanish names); the National Program of Higher Education Scholarships (PRONABES); the Extraordinary Funds to Support State Public Universities (FAEUP); and the creation of polytechnic and intercultural universities. The first three programs basically offer extraordinary funds at different levels: faculty, research, infrastructure, graduate education, and low-income students, among others; the fourth initiative stresses the creation of other tertiary education alternatives.

Examining the focus of the Fox administration's main initiatives on higher education shows limited policies that have neglected some of the major national problems in this sector. In the best scenario, some of Fox's main policies represent just a continuation of previous programs-not necessarily a wrong approach; however, in fact most of the main problems in Mexican higher education were not addressed after the political transition, which reveals the challenge of improving higher education institutions, solving their problems, and enhancing their effectiveness.

PIFI is perhaps the best example of Fox's approach. Its main purpose has been to integrate other government funding programs to support higher education institutions. PIFI includes the following programs: PROMEP (the Faculty Improvement Program), established by President Zedillo in I996 to fund professional and academic faculty development; FOMES (the Fund for the Modernization of Higher Education), created under the Salinas administration in I990 to "modernize" higher education institutions; and FIUPEA (the Fund for Public Universities with Accredited and Evaluated Programs), established to finance universities whose programs have been accredited by the corresponding national boards. PIFI includes other programs for improving infrastructure, modernizing administration, and supporting graduate education (a continuation of a program cosponsored by the National Council for Science and Technology). In sum, innovation does not characterize PIFI.

In this scenario, perhaps the most original and significant initiative, officially promoted within the Fox administration is the higher education scholarship program (PRONABES). In 2001/02, 44,400 scholarships were awarded; in 2005/06 it is estimated that 150,000 students of low socioeconomic status will benefit from the program. First-year students at public institutions (private institutions are not allowed to participate) receive about US\$67 dollars per year; second-year, about US\$79; third-year, US\$89; and fourth-year, US\$I44. These scholarships seem inadequate, but no doubt they have benefit- 